\title{
SELERA KEINDAHAN WARGA TIONGHOADI SEMARANG: STUDI KASUS TRANSFORMASI FUNGSI MUSIK HIBURAN KE RITUAL
}

\author{
Teguh Hartono Patriantoro \\ Program Studi Film dan Televisi, Fakultas Ilmu Komputer \\ Universitas Dian Nuswantoro, Semarang \\ E-mail: teguhhp@dsn.dinus.ac.id
}

\begin{abstract}
Abstrak
Artikel ini menganalisa tentang selera keindaan yang mendapatkan intervensi dari politik praktis. Kondisi politik yang dimaksudkan adalah adanya INPRES no. 14 tahun 1967 yang berisi tentang larangan bagi Masyarakat Tionghoa di Indonesia untuk menggelar acara budaya di depan umum. Munculnya Inpres tersebut mempengaruhi eksistensi Masyarakat Tionghoa dan menyebabkan para pelaku seni untuk merubah fungsi musik yang awalnya bersifat hiburan menjadi pseudo ritual. Proses perpindahan fungsi tersebut juga berdampak pada letak keindahan, dimana ungkapan spontan seperti "ciamik", perasaan kagum, dan gesture bahagia tereduksi secara politis. Pemeliharan pola dari pemerintah dengan adanya INPRES serta tuduhan subversif bagi warga negara yang melanggar, menyebabkan struktur kultural musik menjadi berubah pula. Seperti pemilihan lagu yang harus menghilangkan syair duniawi, pemilihan tempo musik dengan irama dinamis, dan genre musik. Hal ini menyebabkan letak citarasa keindahan dalam bermusik tidak bersifat universal, dikarenakan adanya kerinduan dari masyarakat setelah terbebas dari INPRES. Tujuan dari artikel ini adalah menganalisa bentuk pembelajaran/penularan ilmu kepada generasi berikutnya dengan penyesuaian kondisi eksternal seperti faktor sosial, politik, dan ekonomi. Metode yang digunakan adalah pendekatan antar bidang dengan payung utama etnomusikologi.
\end{abstract}

Kata kunci: ciamik, estetika Tionghoa, transformasi musik, ritual

\section{CHINESE'S TASTE OF BEAUTY IN SEMARANG: CASE STUDY ON THE TRANSFORMATIONAL FUNCTION OF MUSIC FROM ENTERTAINMENT INTO RITUALS}

\begin{abstract}
This article analyzes the sense of desire that gets intervention from practical politics. The intended political condition is the existence of INPRES no. 14 of 1967 which contained a prohibition on Chinese Communities in Indonesia to hold cultural events in public. The emergence of the INPRES influenced the existence of the Chinese community and caused the perpetrators of the arts to change the function of music which was originally as an entertainment into a pseudo ritual. The process of transferring this functionalso affects the aesthetics location, where spontaneous expressions such as "ciamik", feelings of awe, and gesture of happiness are reduced politically. The pattern maintenance from the government with the INPRES and allegations of subversion for citizenswho violatecauses the change of music cultural structure as well. Like the selection of songs that must eliminate worldly lyrics, using dynamic rhythms as the tempo, and musical genres. This causes the aesthetics of music cannot be enjoyed universally, due to the longing of the community after being freed from the INPRES. The purpose of this study is to analyze the form of learning or transmission of knowledge for the future generations with adjustments to the
\end{abstract}


conditions of social, political, and economic factors. The method used is the integrated approach concerning in ethnomusicology.

Keywords: ciamik, Chinese aesthetics, musical transformation, pseudo ritual

\section{PENDAHULUAN}

Kondisi geografis Kota Semarang yang memiliki pelabuhan sebagai gerbang masuknya budaya, menyebabkan kota ini memiliki percampuran etnis di dalamnya. Etnis yang menghuni Kota Semarang antara lain adalah keturunan Timur Tengah, Keturunan Tiongkok, dan Pribumi. Ketiga etnis tersebut hidup berdampingan dan menyebabkan Semarang memiliki identitas budaya yang unik. Keunikan yang dimaksudkan adalah munculnya binatang mitologi berupa Warak Ngendog yang oleh pemerintah dijadikan sebagai icon Kota Semarang. Hewan mitologi tersebut berbentuk kepala naga (melambangkan adanya masyarakat Tionghoa di Semarang), badan Buroq (melambangkan warga keturunan Timur Tengah), dan ekor sapi (melambangkan penduduk pribumi yang saat itu memeluk agama Hindu). Perpaduan 3 etnis tersebut dapat di temui di daerah Kota Lama Semarang.

Ketiga etnis di Semarang yang sampai saat ini masih berlomba-lomba untuk mengeksiskan diri lewat kebudayaan adalah Warga Tionghoa. Paska Reformasi, segala aktivitas warga Tionghoa di Indonesia selalu menyita perhatian dari khalayak umum. Hal ini dikarenkan adanya kerinduan terhadap budaya leluhur mereka yang sudah lama tertidur akibat INPRES no. 14 tahun 1967. Pemerintahan alm. Gus Dur yang mencabut INPRES tersebut lambat laun mengakibatkan masyarakat Tionghoa berlomba-lomba untuk mengeksiskan diri dan menggelar acara kesenian tradisionalnya.

Pemerintah Kota Semarang yang melihat euforia seni Tiongkok kembali digelar dimuka umum, menyambut baik fenomena tersebut; bahkan pemerintah lewat Dinas Pariwisata telah mengagendakan beberapa acara khusus dan memberikan ruang ekspresi bagi mereka.

Bentuk kepedulian pemerintah terhadap etnis Tionghoa tercermin dalam suasana kondusif saat perayaan Imlex yang selalu digelar secara besar-besaran di Kampung Semawis Semarang. Acara tersebut sengaja dikemas untuk mendatangkan wisatawan dari luar kota yang dapat dijadikan sebagai sumber devisa daerah.

Euforia masyarakat Tionghoa dan penduduk lokal yang sempat menyita perhatian khalayak umum sejak pertama kali kemunculannya (tahun 2005) adalah perayaan 600 tahun Pelayaran Muhibah Laksamana Zheng He ke Semarang. Atmosfer keindahan Kota Semarang yang seketika itu berubah menjadi negara Tiongkok, tergambar dari pesta lampion, kembang api, dan hingar bingar musik Tiongkok.

Jalan Semawis yang mayoritas dihuni oleh etnis Tionghoa, berubah menjadi Negeri Tiongkok lengkap dengan aroma dupa dan atribut bernuansa merah, emas, kuning yang melambangkan kemeriahan bagi Warga Tionghoa. Begitu juga dengan spot pertunjukan yang turut memeriahkan acara. Beberapa kesenian etnis yang ikut memeriahkan suasana berhasil menghimpun penonton yang saat itu sedang melintas.

Aktivitas seni dari Warga Tionghoa di Semarang sangat menarik untuk dicermati, mengingat dengan pemberlakuan INPRES dan adanya tuduhan subversif yang ditujukan bagi keturunan Tionghoa yang melanggar, mengakibatkan eksistensi dari kesenian ini mengalami perubahan. Selain itu minimnya literatur tentang kesenian etnis Tionghoa juga layak dijadikan sebagai media pembelajaran ke generasi selanjutnya.

\section{METODE}

Pendekatan yang digunakan dalam penelitian ini adalah interdisciplinary approach dengan menggunakan etnomusikologi sebagai payung utama untuk menganalisa data 
kualitatif. Fokus artikel ini membahas tentang letak cita rasa keindahan Masyarakat Tionghoa di Semarang dengan mengambil studi kasus transformasi musik hiburan ke ritual. Pengumpulan data dilakukan dengancara studi literasi, studi dokumen, wawancara mendalam, observasi partisipan. Proses analisis data ditelaah melalui 3 jalur, yakni: (1) kegiatan sebagai suatu sistem, (2) penyajian data, dan (3) verifikasi/penarikan kesimpulan (Milles dan Huberman 1992, p. 37).

Langkah akhir dari analisis data adalah verifikasi atau pemeriksaan keabsahan data. Data yang diperoleh dari hasil observasi, wawancara, dan dokumentasi berupa audio visual selanjutnya ditafsirkan hingga penarikan kesimpulan lewat beberapa ahli seperti teman sejawat, informan ahli, dan apresiator musik.

\section{HASIL DAN PEMBAHASAN Hasil}

Seni secara sederhana merupakan bentuk keindahan yang diciptakan oleh manusia; oleh karena itu seni adalah suatu produk/usaha manusia untuk menciptakan segala hal yang sedap dipandang mata dan dapat mendatangkan keindahan dari dalam seni tersebut. Fenomena itulah yang tergambar disetiap perayaan Imlex di Semarang.

Mengamati ataupun membicarakan kesenian selalu tidak dapat dipisahkan dengan konsep estetik yang terpancar dari kesenian tersebut. Nilai keindahan yang selalu dikaitkan dengan aspek indrawi manusia, dalam pemaparannya selalu mencakup nilai-nilai yang tercermin dalam sikap kejujuran, ketulusan, dan kebenaran (Sal Murgiyanto, 2002, p. 27).

\section{Pembahasan}

Logika yang berhasil dirumuskan Ruth Lorand dalam menikmati faktor estetis (1994, p. 101) mengatakan bahwa:

...mencermati sebuah benda "secara estetik" berarti menilainya tanpa pamrih atau menerapkan konsep tertentu. Jika sebuah benda didekati secara estetik, tanpa menunjukkan pamrih dan tanpa mengedepankan konsep-konsep yang ada, kita dapat memberikan kenikmatan yang esensi terhadap karya tersebut. (Lorand, 1994, p. 101).

Kesenian etnis warga Tionghoa yang sempat tertidur karena alasan politis, saat ini dapat dirasakan juga bagi penduduk lokal yang secara genetik tidak memiliki keturunan dari Tiongkok. Penduduk lokal yang sering berbondong-bondong untuk menyaksikan kesenian etnis, biasanya bukan hanya diliputi rasa penasaran, melainkan terbawa dalam suasana keindahan yang terpancar dari kesenian tersebut.

Keindahan yang sering terpancar secara spontanitas lewat kata-kata, tepuk tangan, ekspresi bahagia, heran, gesture pada dasarnya adalah ungkapan kerinduan yang bila dibiarkan terus-menerus bisa mempengaruhi jiwa seseorang. Keadaan jiwa yang terpengaruh oleh suara (musik), lukisan, maupun pertunjukan juga berkaitan erat dengan pengalaman estetis sebelumnya.

\section{a. Estetika seni pertunjukan}

Faktor lain yang dapat dijadikan tolak ukur dalam mendeskripsikan aspek estetis menurut Lorand (1994,p. 102) adalah: jelek (ugly), tanpa makna (meaningless), kitcsh, membosankan (boring), tidak penting (insignificant), dan tidak berkaitan (irrelevant). Enam faktor tersebut adalah hasil perenungan Lorand terhadap karya yang berbentuk benda atau artefak seperti seni rupa; akan tetapi keenam faktor tersebut juga dapat diterapkan untuk menilai zat yang berbentuk audiktif seperti musik.

Musik selalu dikonotasikan sebagai zat audiktif dan dapat ditangkap oleh indera manusia, seperti: (1) melodi, (2) pitch, (3) ritme, (4) tempo, (5) dinamika, (6) harmoni, dan (7) tone colour pada dasarnya adalah ungkapan ekspresi dalam diri manusia yang tertuang lewat alunan nada. Pertunjukan musik dapat dikategorikan jelek (ugly) ketika dalam pementasan tersebut tidak mengikuti kaidah ataupun aturan baku seperti yang terdapat dalam pementasan musik kontemporer. Tatanan dalam bermain musik yang sudah merujuk kepada pakem, baik yang dari barat 
maupun timur, akan terasa aneh bahkan tidak memberikan kenikmatan dan kepuasan jiwa bagi penonton yang mengikutinya apabila komposer menghadirkan komposisi musik yang melawan arus. Arus yang dimaksudkan di sini adalah lawan dari tatanan keteraturan (pakem) yang dapat dikategorikan sebagai deformity. Benturan terhadap tatanan suatu obyek dapat terjadi manakala setiap bagian memiliki aturan dan pola sendiri, tetapi antara aturan yang satu dengan aturan yang lain tidak saling mendukung, bahkan terkesan retak (Sal Murgiyanto 2002, p. 29). Keadaan seperti inilah yang dapat dikategorikan sebagai pertunjukan musik yang jelek (ugly).

Pertunjukan musik dapat dikategorikan tak berarti (meaningless) ketika pertunjukan tersebut dipentaskan dihadapan penonton yang sama sekali tidak mengerti tentang pementasan yang sedang berlangsung. Contoh adalah pertunjukan Orkes Yang Khim ataupun orkes musik barat yang dipentaskan di Gunung Kidul. Masyarakat Gunung Kidul yang notabene sudah akrab dengan musik campursari dan nada-nada pentatonis seperti gamelan, akan merasa aneh bahkan tidak akan mempedulikan pertunjukan musik yang berada dalam lingkup luar budaya mereka. Dalam hal ini keadaan sosial dan habitus sangat menentukan tingkat seseorang dapat memberikan penilaian estetis terhadap karya seni tersebut.

Pertunjukan musik dapat dikategorikan kitsch apabila pertunjukan tersebut sudah terlalu over dalam melakukan eksplorasi musik. Definisi kitsch dapat diterjemahkan sebagai barang indah-alamiah ataupun buatan yang telah teruji dan disalahgunakan dengan jalan mengeksploitasi menggunakan effect demi mendapatkan imbalan tertentu (Jenifer Lindsay 1991, p. 61). Eksplorasi musik yang terlalu berlebihan, kadang dapat menimbulkan kesan naif bagi apresiator musik yang menikmatinya. Fenomena ini juga terjadi dalam Orkes Yang Khim.

Pertunjukan tradisi Tiongkok yang sudah seharusnya menggunakan instrumen musik timur, sengaja digubah oleh para pelaku seni dengan menambahkan instrumen musik barat seperti set drum, keyboard, dan bass guitar. Alasan komposer melakukan penambahan instrumen tersebut lebih didasarkan atas bentuk lagu yang tidak dapat menjangkau nadanada diluar modus Tiongkok untuk kemudian diakomodir dengan instrumen musik barat. Di negeri asalnya, pertunjukan jenis ini memang menggunakan penambahan instrumen musik barat, dan sering membawakan lagu-lagu populer dari barat, akan tetapi semangat dan jiwa yang dihasilkan dari instrumen Tiongkok tetap dimunculkan sebagai identitas mereka. Hal itu juga telah ditepuh oleh pelaku seni Tiongkok di Semarang. Usaha tersebut wajib dimunculkan demi mendapatkan apresiasi dari golongan muda yang notabene sudah akrab dengan instrumen musik barat dan musikmusik ber-genre populer seperti band.

Pertunjukan musik dapat dikategorikan membosankan atau (boring) ketika penyaji musik tidak pernah menghadirkan kejutan yang dapat menimbulkan decak kagum dari penonton. Pertunjukan akan terkesan sangat membosankan lagi apabila dalam penyajian tersebut selalu didominasi oleh pola-pola yang sudah bisa ditebak ataupun diramalkan oleh penonton. Kasus yang menimpa Orkes Yang Khim ketika mereka pentas di dalam klenteng adalah contoh dari fenomena tersebut. Bagi masyarakat Tionghoa yang sering melakukan ritual bertepatan dengan pementasan Yang Khim mungkin akan merasa bosan ketika para pelaku seni selalu memainkan lagu-lagu yang sudah sering mereka pentaskan; akan tetapi mereka memiliki siasat khusus untuk mengatasi hal itu. Formula yang ditempuh untuk mensiasatinya dengan cara mempersilakan pengunjung untuk berpartisipasi sekaligus menyumbangkan lagu, dan sejauh ini usaha tersebut berhasil dengan baik.

Pertunjukan dapat dikategorikan tidak penting (insignificant), atau bahkan lebih ironis lagi tidak berkaitan (irrelevent) ketika pertunjukan tersebut tidak mengindahkan kaidah yang berlaku atau bahkan tidak sejalur dengan norma-norma yang ada. Kasus dalam ranah ini adalah pementasan Orkes Yang Khim ketika klenteng merayakan kenaikan Dewi 
Kwan Im Po Sat ke Nirwana. Pertunjukan Yang Khim yang hanya memiliki fungsi sebagai sarana hiburan, ketika pentas di dalam klenteng tentu saja mereka harus memikirkan hal yang bersifat fundamental seperti memilih tema lagu dan menghidari syair keduniawian.

\section{b. Selera keindahan warga Tionghoa}

Faktor ekternal yang sering mempengaruhi terhadap eksistensi keindahan seni adalah keadaan sosial, politik, dan ekonomi. Hal ini sesuai yang dikatakan oleh (R.M. Soedarsono 2003, p. 69) bahwa: "Seni pertunjukan sebagai salah satu aspek penting dari kehidupan manusia, perkembanganya sangat diwarnai oleh berbagai faktor non seni, dan yang paling signifikan adalah faktor politik, sosial, dan ekonomi. Ketiga faktor inilah yang menentukan sebuah genre atau bahkan seni pertunjukan dalam kehidupan."

Eksistensi masyarakat Tionghoa memang sempat terpinggirkan karena keadaan politik Indonesia, namun karena kemapanan sektor ekonomi dari para pelaku seni, lambat laun mereka berhasil mengeksiskan diri lewat kesenian ritual. Hampir keseluruhan seni pertunjukan Tiongkok di Indonesia pada dasarnya berfungsi sebagai sarana hiburan. Namun, dengan adanya intervensi politik, para pelaku seni berusaha meleburkan kesenianya dan merubah fungsi hiburan kearah ritual. Hal ini bisa ditemui dari kemunculan seni pertunjukan Tiongkok era Orde Baru.

Para pelaku seni yang saat itu takut dan menghindari tuduhan subversif berlombalomba untuk memainkan musik di dalam Klenteng sebagai sarana ritual. Tentu saja hal ini kurang mendapatkan apresiasi dari masyarakat luas yang tidak berkepentingan untuk bersembahyang. Tindakan ini dapat dikatakan sebagai pemeliharaan pola (Nurhadi 2009 , p. 257). Pola yang dimaksudkan disini adalah adaptasi dari struktur tindakan AGIL (Adaptasi, Goal, Integrasi, Latensi) oleh Talcott Parson. Skema tersebut terdiri dari sistem kultural, organisme behavioral, sistem sosial, dan sistem kepribadian (George Ritzer 1991, p.207)

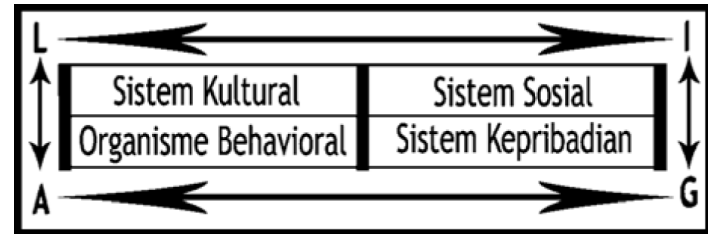

Gambar 1. Alur struktur tindakan AGIL menurut Talcott Parson

Struktur tindakan dalam hal ini dapat diterjemahkan dari kemunculan INPRES no. 14/INPRES/1967 yang berisi tentang larangan segala aktivitas leluhur budaya China untuk dipergelarkan di luar tempat ibadah. Kondisi politik Indonesia dengan adanya larangan tersebut telah membentuk sistem kultural masyarakat Tionghoa di Indonesia dan Semarang pada khususnya untuk merubah segala macam aktivitas seni yang awalnya bersifat hiburan beralih menjadi pseudo ritual. Akibat yang muncul dari pergeseran fungsi tersebutadalah generasi berikutnya yang kurang mengerti tentang perubahan politik. Generasi muda yang minim informasi akan menyalahkan selera musik dengan mengedepankan konsep ritual yang sebenarnya terbentuk dari atmosfer politik. Pemilihan selera yang mengedepankan konsep ritual tersebut, sepanjang perjalananya sangat sulit untuk dilogika.

Sistem sosial yang terdapat dalam diagram AGIL dapat diartikan sebagai tatanan masyarakat yang terbentuk dari kesatuan etnis yang berbeda. Letak geografis Kota Semarang yang dihuni oleh 3 etnis besar, yakni Pribumi, Keturunan Timur Tengah, dan Tionghoa (R. Anderson Sutton 1991, p. 101) telah mengakibatkan adanya percampuran orientasi. Sebagai contoh masyarakat keturunan Timur Tengah yang sejak awal kedatangan ke Indonesia untuk berdagang, kemudian disusul oleh masyarakat Tionghoa yang bermaksud untuk migrasi dan perluasan wilayah. Pertemuan kepentingan tersebut lambat laun menjauhkan seni tradisi keorientasi bisnis dan menghindarkan mereka dari pemeliharaan pola berkesenian, sekaligus terbebas atas tuduhan subversif yang diberlakukan pemerintah saat itu. 
Sistem kultural yang dapat mempengaruhi selera seseorang untuk mendiskusikan keindahan juga dapat dipengaruhi oleh faktor yang terbentuk dari kondisi politik. Hal ini terlihat dari para pelaku kesenian yang mayoritas didominasi oleh lansia. Minimnya regenerasi yang dilakukan adalah strategi para pelaku musik saat itu dan adanya pesanan untuk merubah musik hiburan ke ranah ritual. Tindakan ini ditempuh demi mengeksiskan kesenian mereka dan adanya harapan akan transisi politik. Tindakan pelaku musik untuk tidak meneruskan aktivitasnya ke generasi muda didasari oleh penyelamatan keturunan mereka dari tekanan politik saat itu.

Sistem kepribadian yang dapat dianalisa dari diagram AGIL adalah kondisi psikologis para pelaku kesenian untuk tetap menghadirkan seni hiburan menjadi pseudo ritual di dalam Klenteng. Tentu saja hal ini bertentangan dengan kaidah hiburan dan letak keindahanya, mengingat syair dan irama musik yang dinamis harus bertransformasi menjadi lebih tenang, terhindar dari lirik duniawi, dan penggunaan atribut gemerlap. Pola garapan lagu yang diaransemen otomatis harus mengedepankan suasana sakral dan tetap mempertunjukan keindahan yang hakiki.

\section{KESIMPULAN}

Manusia sebagai individu yang unik sekaligus sempurna pada kenyataannya tidak dapat dipisahkan dengan fenomena sosial yang berada di luar dari kehidupan dan habitus mereka. Ekspresi diri yang secara spontan/ bahkan telah direncanakan sebelumnya dalam bermusik, secara tidak langsung belum mampu mengatasi universality dalam bermusik jika musik tersebut diterapkan untuk menilai keindahan dari musik timur. Fenomena itu yang kebanyakan dialami oleh kurator musik di dunia. Sebagai contoh adalah seseorang yang sudah terbiasa memainkan atau mendengarkan nada-nada makro diatonis seperti dalam musik barat, akan terasa sulit bahkan aneh ketika mendengarkan musik timur yang notabene memainkan nada-nada mikro pentatonis yang lebih dikenal dengan istilah cengkok.
Letak cita rasa keindahan menurut masyarakat Tionghoa di Semarang yang tercermin dalam kata "ciamik", pada dasarnya adalah ekspresi dari pribadi mereka karena adanya kerinduan terhadap budaya Tiongkok yang sudah lama tertidur karena INPRES NO.14 tahun 1967. Kata pungtif dari “ciamik"yang tertuang secara spontan ketika melihat seni pertunjukan Tiongkok diadaptasi dengan kearifan lokal, didukung juga oleh penampilan para pemain yang rata-rata usianya berumur 60 tahun ke atas.

Keindahan aransemen musik dengan caramenambahkan instrumen musik barat dan tidak mereduksi semangat ataupun ciri khas musik Tiongkok telah berhasil merebut hati para penonton yang hadir saat itu. Komposer yang sengaja memasukan lagu-lagu Jawa ataupun lagu Tiongkok yang sudah diterjemahkan ke dalam bahasa Indonesia, seperti lagu "Tian Mi Mi" menjadi lagu keroncong "Dayung Sampan" juga menjadi alasan pokok pertunjukan mereka mendapatkan sambutan yang meriah ketika pentas.

\section{DAFTAR PUSTAKA}

Banoe, Pono. 2003. Kamus Musik. Yogyakarta: Kanisius.

Danandjaja, James. 1994. Antropologi Psikologi. Jakarta: PT Raja Grafindo Persada.

Djelantik, A.A.M. 2004. Estetika: Sebuah Pengantar. Bandung: MSPI.

Eberhard, Wolfram. 1993. a Dictionary of Cinese Symbol: Hidden Symbol in Chinese Life and Thought. New York: Roudledge

Hadi, Y. Sumandiyo. 2006. Seni dalam Ritual Agama. Yogyakarta: Buku Pustaka.

Liliweri, Alo. 2003. Dasar-dasar Komunikasi Antar Budaya. Yogyakarta: Media Abadi.

Lindsay, Jenifer. 1991. Klasik, Kitch, Kontemporer. Yogyakarta: Gadjah Mada University Press.

Lorand, Ruth. 1994. Beauty and its Opposites: Art and Criticism. Fall

Mark, Dieter. 2004. Musik Kontemporer dan Persoalan Interkultural. Bandung: ARTI. 
Mark, Dieter. 2007. Sejarah Musik Jilid 4. Yogyakarta: Pusat Musik Liturgi.

Morgan, Harry T. 2007. China: Simbol dan Mistik. Yogyakarta: Alfamedia.

Murgiyanto, Sal. 2002. Kritik Tari: Bekal dan Kemampuan Dasar. Jakarta: MSPI.

Nakagawa, Sign. 2000. Musik dan Kosmos: Sebuah Pengantar Etnomusikologi. Jakarta: Yayasan Obor.

Purwanta, H. 2009. Sejarah Cina Klasik. Yogyakarta: Universitas Sanata Dharma.

Prier, Karl Edmund. 2002. Sejarah Musik Jilid 1. Yogyakarta: Pusat Musik Liturgi.

Salim, Djohan. 2005. Psikologi Musik. Yogyakarta: Buku Baik.

Schechener, Richard. 2006. Performance Studies: an Introduction, second edition. Inggris: Routledge.
Sutton, R. Anderson. 1991. Traditions of Gamelan Music in Java: Musical Pluralism and Regional Identity. New York: Cambridge University Press.

Soedarsono, R.M. 2002. Seni Pertunjukan Indonesia di Era Globalisasi. Yogyakarta: Gadjah Mada University Press.

Soedarsono, R.M. 2003. Seni Pertunjukan dari Perspektif Sosial Politik dan Ekonomi. Yogyakarta: Gadjah Mada University Press.

Tan, Melly G. 2008. Etnis Tionghoa di Indonesia. Jakarta: Yayasan Obor. 